\title{
THE IMPACT OF COVID-19 ON NATURAL GAS MARKETS IN 2020
}

\section{Dinu Florinel ${ }^{1}$, Aidoni Artemis ${ }^{2}$, Oprea George Iulian ${ }^{3}$}

\author{
${ }^{1}$ Petroleum - Gas University of Ploiesti, Romania \\ ${ }^{2}$ Enel Romania S.A., Romania \\ ${ }^{3}$ S.C. Petrostar S.A., Romania \\ e-mail: artemisaidoni60@gmail.com
}

DOI: $10.51865 / J P G T .2021 .01 .02$

\begin{abstract}
A warm start to the year 2020 coupled with the impacts of the COVID-19 pandemic had a devastating impact on the Oil and Gas sector across the globe. A great economic shock was felt throughout this period and continued until the end of the year and even during the next year, but the extent of the damage is still uncertain, as is the speed and scale of recovery. Owing to the global lockdowns that resulted from the COVID-19 pandemic, gas consumption and production plummeted and the prices reached a new record low.

As the pandemic started to spread in Europe the gas production went below the 20152019 range reflecting the decreasing trend of gas production in EU. In the same period 5 years ago the gas production was $36.6 \mathrm{bcm}$, more than twice as in Q1 2020, illustrating the rapid decrease in gas production in the block of 27 and the increase in import dependenc in natural gas. This study highlights the effects of COVID-19 on the gas markets based on publications of National Regulatory Authorities, Transmission System Operators, International Energy Agency, one of the world's most trusted providers of data of global commodities markets and European Energy Exchange.

Under the optimistic infection scenario, gas demand will recover close to the nonpandemic level by 2021. Unfortunately, the oversupply situation is improbable to be overcome promptly and in a more pessimistic way there is no visibility for a better business environment before 2023 .
\end{abstract}

Keywords: COVID19, production, consumption, Europe, prices.

\section{INTRODUCTION}

While the Covid-19 pandemic was creating significant uncertainty for the wider energy sector, the gas sector was already facing some serious troubles of its own making even prior to the crisis with the supply and demand imbalance already in effect.

The oil and gas sector was caught up by the coronavirus pandemic while it was wavering between oversupply and low demand, the pandemic leaving its mark by 
further depressing demand. The impact of the virus is primarily being seen on the demand side with an unprecedented drop in general, for the industry, but particularly for oil and gas.

As a consequence of the COVID-19 crisis, world oil production in 2020 was, on average, 94.7 million barrels/day, 6\% lower than in 2019, a historic drop, with total OPEC supply representing $30 \%$, down by $5 \% \mathrm{y} / \mathrm{y}$.

Moreover, April 20, 2020 will go down in the history as the first time when the price of oil reached a negative value. In consequence, those who held buying positions on contracts in May 2020 were forced to pay in order to sell these contracts because it would be difficult to store the volume of oil that they should receive.

\section{EUROPEAN GAS DEMAND}

The outbreak of the Covid-19 pandemic created an unequalled shock to the global energy system, and gas consumption across the world was significantly impacted. Because of lower electricity use the gas demand declined in the power sector and also in the industrial and commercial sector due to shutdowns of businesses and factories.

"In the first five months of 2020, natural gas demand in Europe have declined by about 8 percent or $19 \mathrm{bcm}$ year on year" [2] (Figure 1). The fall was driven by the successive impacts of mild temperatures, high renewables in power generation and the consequences of COVID- 19.

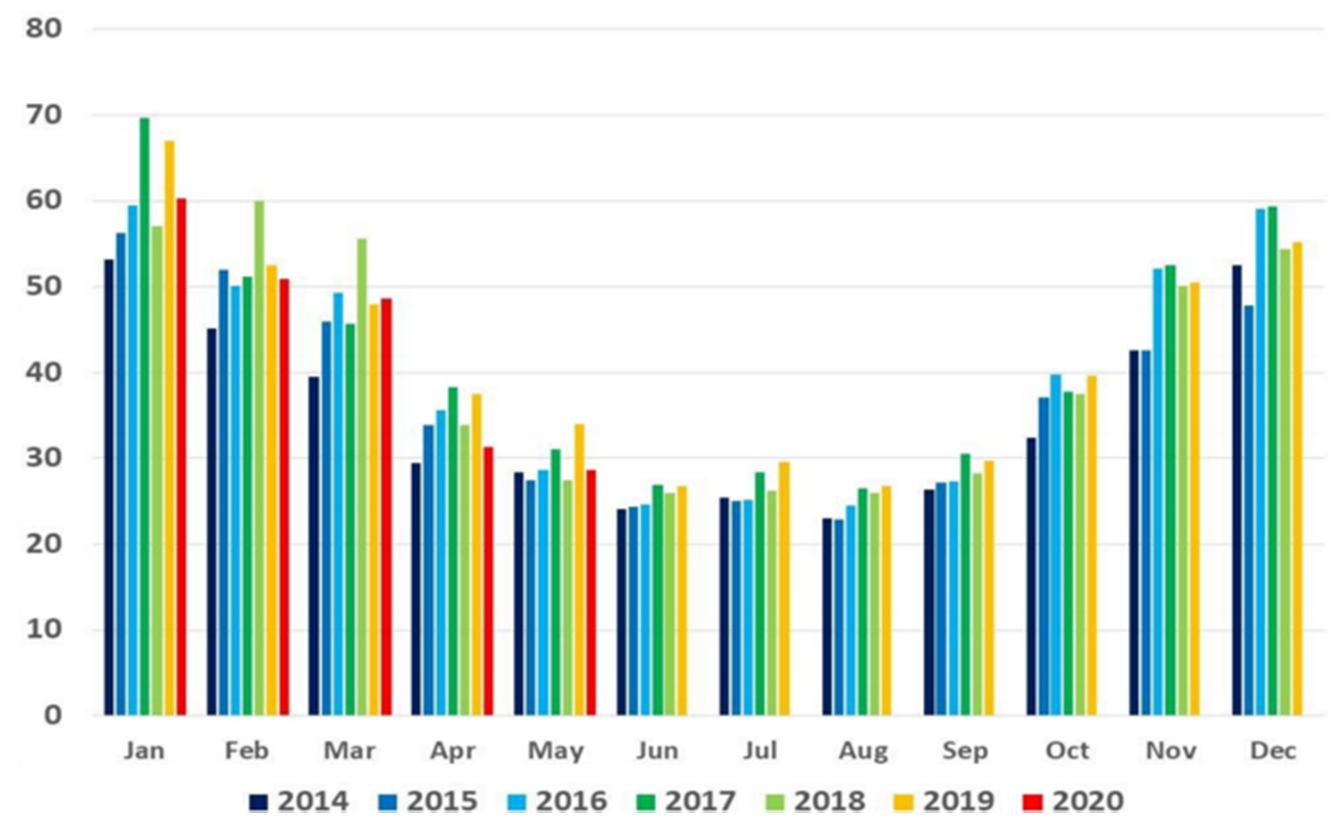

Figure 1. Monthly natural gas demand in Europe (bcm) [8]

Due to the warm temperatures, wet and windy weather on winter 2019-2020 the gas demand in Europe was already week even before the COVID-19 pandemic reached its full extent. A combination of factors not advantageous to high gas demand seen in January limited the need for gas used for heating in buildings as well as heating-related electricity consumption. As a result, gas demand was down by 10 per cent year on year in January and by 3 per cent in February [2] (calculated from IEA and Eurostat data). 
In March, the number of COVID-19 cases increased rapidly and Europe became the epicentre of the new coronavirus pandemic. On 11 March 2020, Italy issued a nationwide lockdown being followed by many other European countries within a week or two. Countries closed their borders and introduced strict restrictions on people movement.

Constraint policies were not uniform across Europe, but with various degrees of restriction, geographical coverage and starting dates. The measures lead to huge economic and social costs as the social distancing was encouraged, public events were banned, schools were closed and most non-essential retail and manufacturing activities shut down or ordered to operate at minimum levels for several weeks. The effect of reduced activity or even temporary closure of power-intensive manufacturing and retail shops, restaurants/cafes and offices on demand for gas started to be seen in the second half of March in the industrial and power generation sectors in most countries, but at varying degrees, depending on the severity of early lockdown measures.

The European gas consumption in Q1 2020 corresponded to $131 \mathrm{bcm}$, in comparison with $163.1 \mathrm{bcm}$ in Q1 2019 (Figure 2). In percentages, the gas consumption decreased more than 20\% in Romania, Latvia, Finland and Slovakia, whereas in Estonia it also fell by $14 \%$ in year-on-year comparison and in the United Kingdom by $4.5 \%$ (1.2 bcm).

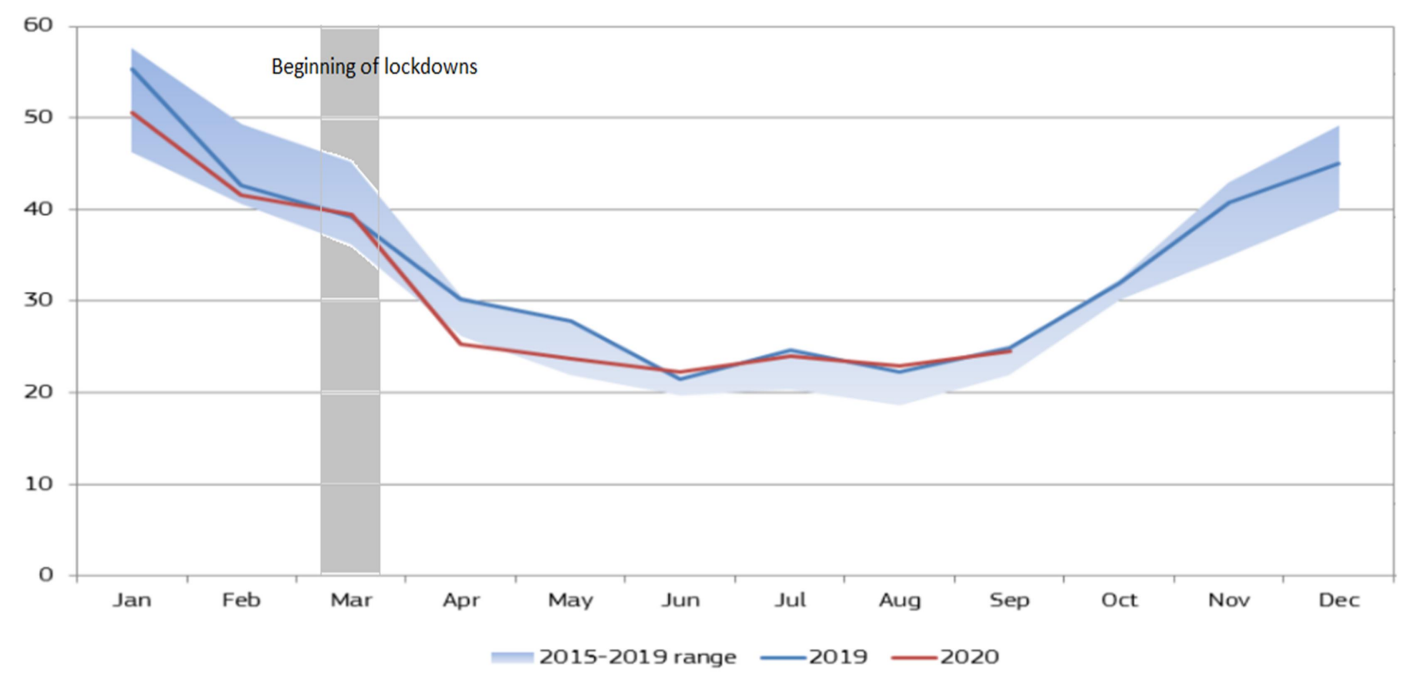

Figure 2. Evolution of European natural gas consumption, 2019 and 2020 (bcm) [9]

However, in the same period Malta registered the biggest year-on-year increase in gas consumption $20 \%$, though representing only a minor increase of $0.02 \mathrm{bcm}$. Gas consumption went up in Portugal (by $17 \%, 0.2 \mathrm{bcm}$ ) and in Hungary and Croatia ( $4 \%$ in both, and respectively by $0.2 \mathrm{bcm}$ and $0.04 \mathrm{bcm}$ ).

"In absolute numbers, gas consumption in Q1 2020 decreased the most in Germany and Italy (both by $1.7 \mathrm{bcm})$, Romania $(1.3 \mathrm{bcm})$, France $(1.1 \mathrm{bcm})$, Slovakia $(0.4 \mathrm{bcm})$, Spain $(0.3 \mathrm{bcm})$, and Finland $(0.2 \mathrm{bcm})$ " [3]. 


\section{NATURAL GAS PRODUCTION IN EUROPE}

The gas production fallen by $16 \mathrm{bcm}$, aprox. 23\% less year-on-year for the same period with the biggest European gas producing countries, including the Netherlands $(-33 \%$, the steepest fall in the last six years) and Romania cutting their production. In the first three months of 2020 a strong decrease was registered at Netherlands which produced $7.2 \mathrm{bcm}$ of gas, followed by Germany $(1,3 \mathrm{bcm})$ and Italy $(1,1 \mathrm{bcm})$, respectively down by $32 \%, 13 \%$ and $15 \%$ registered in Q1 2019. The gas production in Romania and UK also dropped for Q1 2020 but not sharply, registering only a drop of 4\% and 2\% (Figure $3)$.

During the first quarter of 2020 the gas production was below the 2015-2019 range reflecting the decreasing trend of gas production in EU. In the same period 5 years ago the gas production was $36.6 \mathrm{bcm}$, more than twice as in Q1 2020, illustrating the rapidly decrease in gas production in the block of 27 and the increase in import dependency in natural gas.

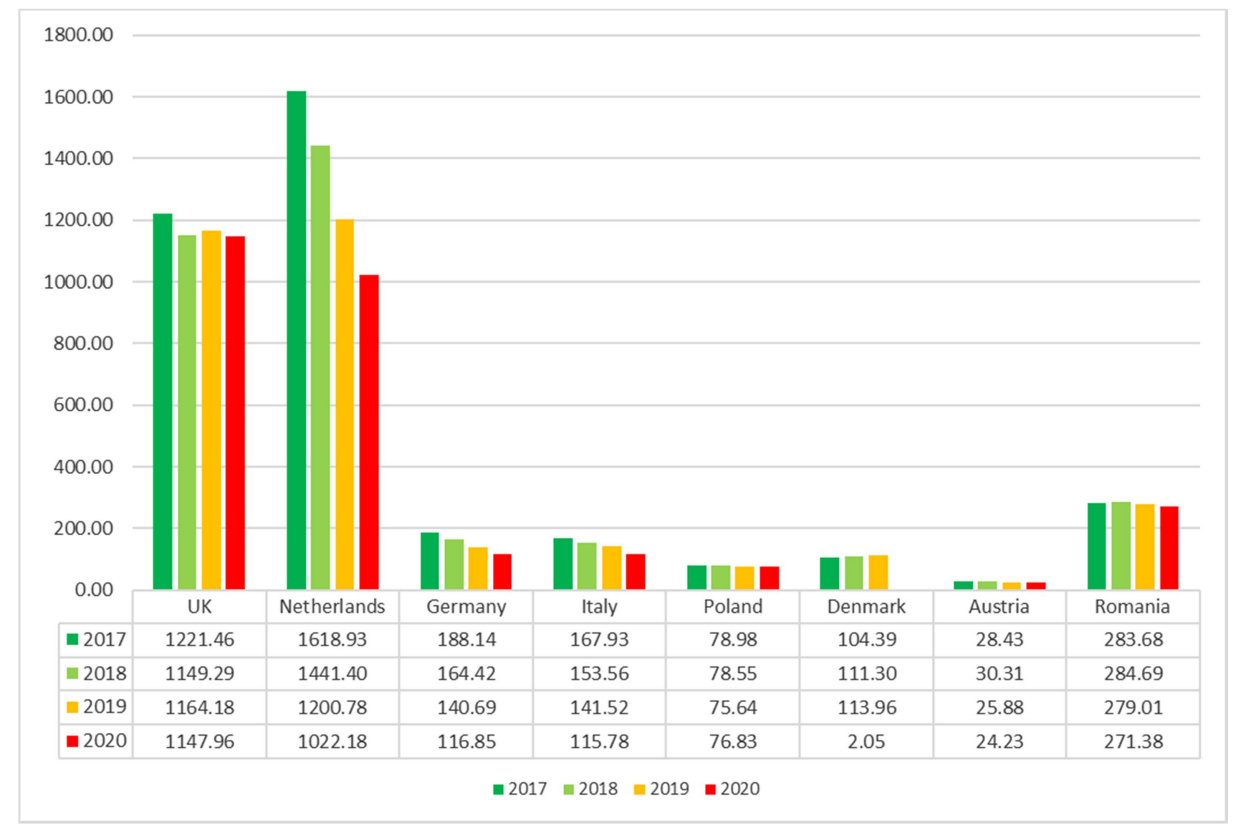

Figure 3. Natural gas production for Q1 2020 (GWh/day) [10]

The downward trend in the Groningen field and also in other smaller fields in Netherlands indicates the rapid fall in Dutch domestic gas production. From $17.5 \mathrm{bcm}$ in 2018 , less than the allowed maximum, it fell to $11.8 \mathrm{bcm}$ for the gas year 2019 and to $8.1 \mathrm{bcm}$ in 2020 with a forecast that in 2022 the production will cease completely.

Following in Netherland's footsteps, gas production in Denmark strongly decreased, 98\% in 2020 according to Danish Energy Agency's results. Production has been constrained since the Tyra field was shut down for redevelopment, which is not expected to be completed until de second quarter of 2023. Moreover, Denmark cancelled new oil and gas permits and set date to end existing production. "Gas output went down in Germany, Italy and Ireland by $0.2 \mathrm{bcm}$ each (in percentage change respectively by $13 \%, 17 \%$ and $20 \%$ ), " [3] whereas in Norway gas production decreased by $1 \mathrm{bcm}, 3.4 \%$, in Q1 2020 compared to the same period last year. 
In mid-April of 2020 in various European countries a cautiously relaxation of restrictions has taken place taking into consideration the reduction of infections with new COVID-19, however, in both April and May gas demand in Europe was down by 16 per cent year on year. During May there were seen some signs of cautious recovery, for instance, in the industrial sector in Italy, due to the gradual reopening of the economies, even if gas demand remained considerably lower than in 2019: "gas use in power plants was down by $11 \%$ in Italy and Spain in the last week of May, compared to business-as-usual and industrial gas demand declined by $11 \%$ in Italy and by $14 \%$ in Spain compared to expected demand" [4].

In percentages, the gas production in the second quarter of 2020 decreased approx. $20 \%$ in Romania, Germany and Netherlands, in Italy it also fell by $15 \%$ in year-on-year comparison, whereas in the United Kingdom was up by $6 \%$ despite reduced demand because planned maintenance was postponed ensuring there was minimal manning at terminals to aid with social distancing during the Covid-19 pandemic.

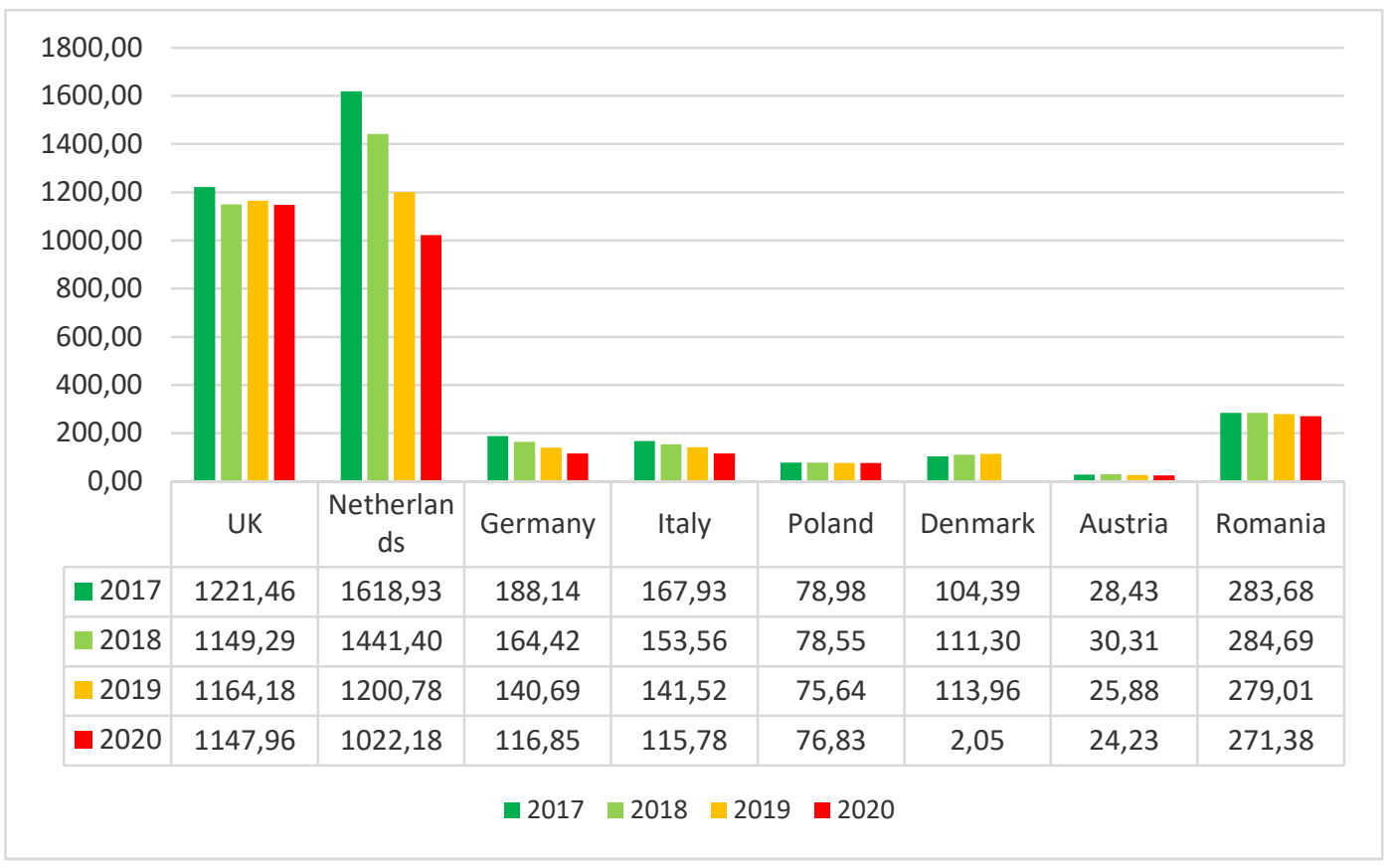

Figure 4. Natural gas production for Q2 2020 (GWh/day)

In more detail, in Romania, the major domestic companies SNGN Romgaz and OMV Petrom continue to reduce their production since the beginning of the year. At the start of April their production was diminished by approx. $8.5 \%$ in just 2 weeks, adapting to the collapse of consumption, which decreased on average by almost $40 \%$. "If on April 1 and 2, 2020 the consumption in Romania was $400 \mathrm{GWh} /$ day, and the production of approx. $272 \mathrm{GWh} /$ day, on April 23, 2020 the consumption decreased to $246 \mathrm{GWh} /$ day, and the production to $249 \mathrm{GWh} /$ day" [1]. The additional production from the days when it was higher than the consumption was stored. In consequence, the total storage capacity increased from $12.5 \%$ from last year to $59 \%$ at the same period of 2020 , this corresponding to a quantity of $4.1 \mathrm{TWh}$ respectively $19.4 \mathrm{TWh}$. Furthermore, the increased rate of filling of deposits and especially the reduction of gas consumption as the result of the quarantine put considerable pressure on the price. 


\section{GAS PRICE ANALYSIS}

In the first three quarters of 2020 the fall of the price for the day ahead contract compared to the same period of 2019 was approx. $47 \%$ as it results from the table below (Table 1).

Table 1. Average price of day ahead contract based on the monthly natural gas market monitoring report published by ANRE

\begin{tabular}{|c|c|c|c|}
\hline \multicolumn{5}{|c|}{ DAY AHEAD } \\
\hline \multicolumn{2}{|c|}{ Average price (lei/MWh) } & \multicolumn{2}{c|}{ Average price (lei/MWh) } \\
\hline Jan-19 & 139.89 & Jan-20 & 71.75 \\
\hline Feb-19 & 97.18 & Feb-20 & 67.40 \\
\hline May-19 & 83.51 & Mar-20 & 59.55 \\
\hline Apr-19 & 91.80 & Apr-20 & 51.58 \\
\hline May-19 & 106.24 & May-20 & 40.98 \\
\hline Jun-19 & 97.16 & Jun-20 & 46.11 \\
\hline Jul-19 & 97.89 & Jul-20 & 39.73 \\
\hline Aug-19 & 105.18 & Aug-20 & Sep-20 \\
\hline Sep-19 & 101.57 & & \\
\hline
\end{tabular}

Figure 5. Evolution of European natural gas prices for day ahead contract, 2019 and $2020(E U R / M W h)[11]$

The pressure on natural gas prices have been felt to all of the European countries on the back of the sliding oil price. In the first half of this year, European gas prices touched record lows after a glut of LNG came to Europe and coronavirus lockdowns (Figure 4). But the situation is not the same for the second half of the year. The production in August decreased about $21.89 \%$ in Germany, $19.43 \%$ in Romania and big percentages were also registered for the rest of the gas production countries and also by $22.05 \%$ as an average in September and by 14\% in Q4 (Figure 6, 7). Some other key factors in the strength of gas prices in the end of Q3 were demand recovery, low French nuclear, scarce renewable and hydro output, and weak coal economics. In Q4 the bullish sentiment remains, after a fall in November, as demand grows more than supply and the Continental balance switches to storage withdrawals due to a weakness in LNG deliveries. 
Also, "on 10.12.2020, the Federal Drug Administration voted to approve the Pfizer COVID-19 vaccine for emergency use authorization, the price per barrel being back in the mid-\$40 range, and continuing rising" [7] especially after vaccination against COVID-19 started on 27 December 2020 across the European Union.

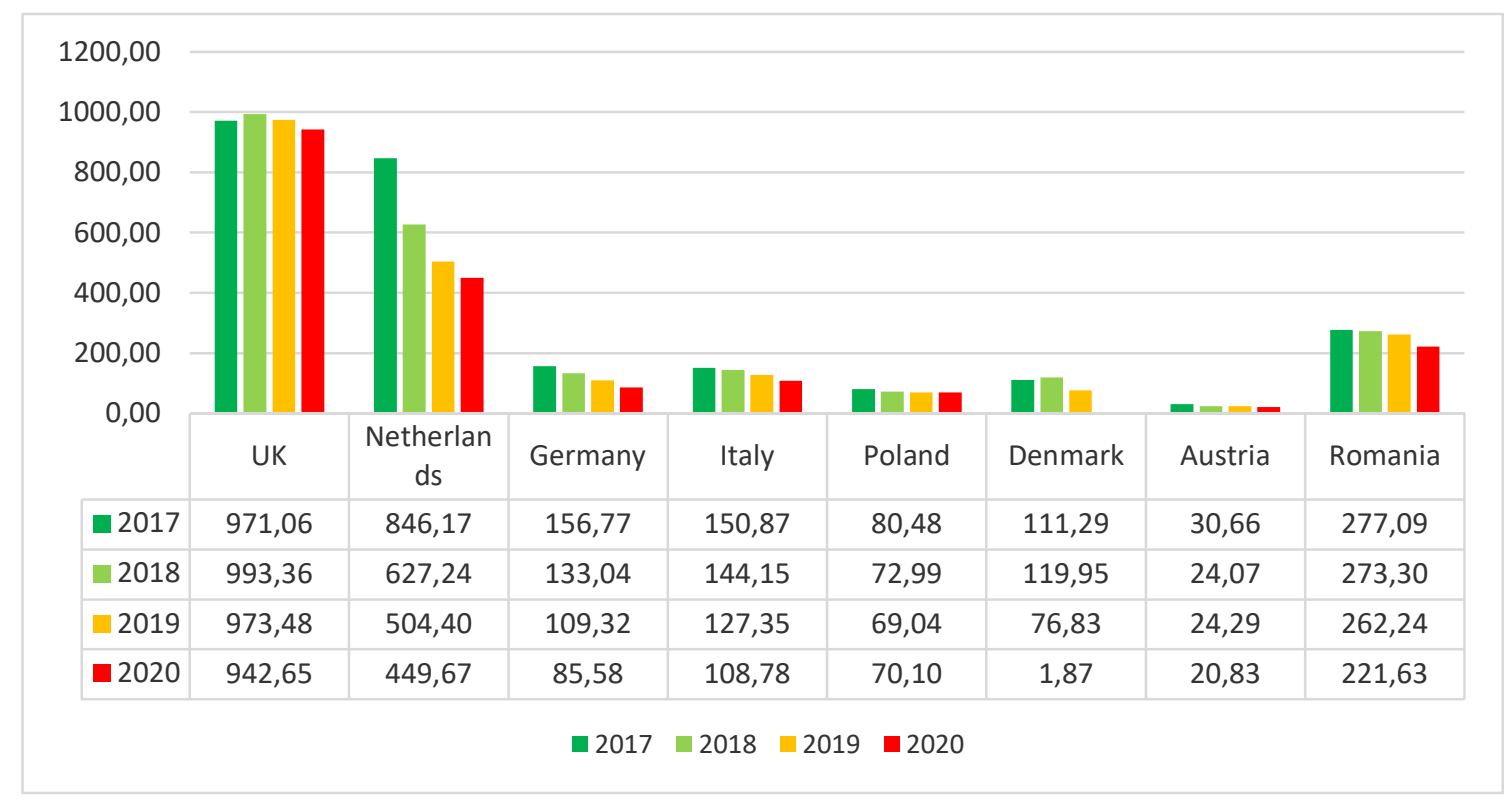

Figure 6 Natural gas production for Q3 2020 (GWh/day)

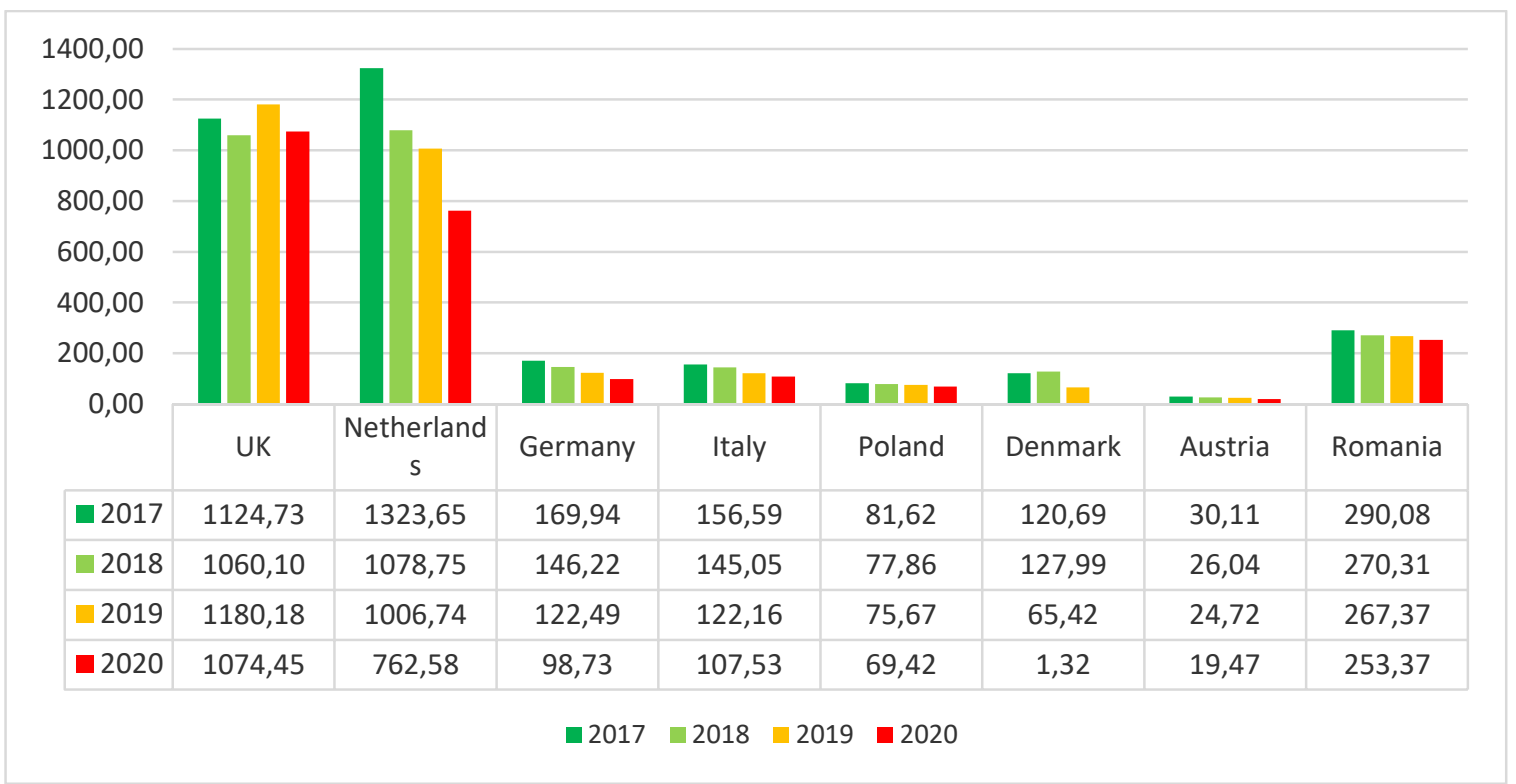

Figure 7 Natural gas production for Q4 2020 (GWh/day)

Despite lower economic activity the impact in the U.S. was limited. Natural gas consumption decreased by $2.8 \% \mathrm{y} / \mathrm{y}$ for the first half of the year. The biggest impact was on industrial gas demand due to factory shutdowns. Contrarily, during this period, gas demand in power went up due to low gas prices and to a higher residential gas demand. 
In China, the effects of the Covid19 on gas consumption were quite minimal during early 2020, China succeeding to keep the situation under control from an early stage. Analysing the numbers in a macro time scale we could conclude that the lockdown measures barely caused a decrease in demand, with a growth of $1.6 \%$ in Q1 2020 compared to $14 \%$ in Q1 2019. "Industries restarted gradually from March, which revived demand growth. April demand was 3.8\% higher $y / y$. China's LNG imports were also recovering, and small LNG buyers were taking the opportunity to buy cheap spot LNG" [4].

As the role of the gas varies widely across European countries as an energy supply, not all of them have been affected uniformly by mild temperatures, high renewables in power generation and the consequences of COVID-19. Out of the eight major gas markets only one didn't registered a demand decline. "The largest variations were seen in France, $-13.2 \%$ and in Italy, $-11.5 \%$, though, in Poland was registered a small increase, $2 \%$, as a result to coal to gas switching in its power sector" [2].

\section{LOOKING AHEAD}

The Covid-19 pandemic has a significant and persistent impact on the global economy and energy system. The central view used in the main scenarios is that economic activity partially recovers from the impact of the pandemic over the next few years as restrictions are eased, but that some effects persist. "The level of global GDP is assumed to be around 2.5\% lower in 2025 and 3.5\% in 2050 as a result of the crisis" [5].

A great economic shock was felt throughout this period and continue until the end of 2020 , but the extent of the damage is still uncertain, as is the speed and scale of recovery, as seen in Table 2.

Table 2. Scenarios for economic outlook in Europe in 2020 and 2021.

\begin{tabular}{|c|c|c|c|c|c|c|c|c|}
\hline & \multicolumn{2}{|c|}{$\begin{array}{c}\text { IMF } \\
\text { (April) }\end{array}$} & \multicolumn{2}{c|}{$\begin{array}{c}\text { EU Commission } \\
\text { (May) }\end{array}$} & \multicolumn{2}{c|}{$\begin{array}{c}\text { IMF } \\
\text { (October) }\end{array}$} & \multicolumn{2}{c|}{$\begin{array}{c}\text { OECD } \\
\text { (December) }\end{array}$} \\
\cline { 2 - 9 } & 2020 & 2021 & 2020 & 2021 & 2020 & 2021 & 2020 & 2021 \\
\hline EU27 & -7.1 & 4.8 & -7.4 & 6.1 & -7.0 & 4.7 & - & - \\
\hline Euro area & -7.5 & 4.7 & -7.7 & 6.3 & -8.1 & 5.2 & -7.5 & 3.6 \\
\hline Germany & -7.0 & 5.2 & -6.5 & 5.9 & -6.0 & 4.2 & -5.5 & 2.8 \\
\hline UK & -6.5 & 4.0 & -8.3 & 6.0 & -9.8 & 6.9 & -11.2 & 4.2 \\
\hline Italy & -9.1 & 4.8 & -9.5 & 6.5 & -10.6 & 5.2 & -9.1 & 4.3 \\
\hline France & -7.2 & 4.5 & -8.2 & 7.4 & -9.8 & 6.0 & -9.1 & 6.0 \\
\hline NL & -7.5 & 3.0 & -6.8 & 5.0 & -5.4 & 4.0 & -4.6 & 0.8 \\
\hline Spain & -8.0 & 4.3 & -9.4 & 7.0 & -12.8 & 7.2 & -11.6 & 5.0 \\
\hline Poland & -4.6 & 4.2 & -4.3 & 4.1 & -3.6 & 4.6 & -3.5 & 2.9 \\
\hline Belgium & -6.9 & 4.6 & -7.2 & 6.7 & -6.7 & 4.6 & -7.5 & 4.7 \\
\hline Romania & -5.0 & 3.9 & -6.0 & 4.2 & -4.8 & 4.6 & -5.3 & 2.0 \\
\hline
\end{tabular}


In April the IMF expected a decline of 7.1 per cent of GDP in 2020 before a rebound in 2021. In May the European Commission forecasted a worse scenario for 2020 but followed by a stronger recovery in 2021. The economic and monetary information published in the Economic bulletin in May by the European Central Bank indicated that the GDP in the Euro area could fall between 5 and 12 per cent in 2020.

However, "the so-called ' $\mathrm{V}$ ' shape seemed unrealistic according to its President, Christine Lagarde, and the scenario of only a 5 per cent decline was probably already out of the question" [2].

Nevertheless, in December the Organisation for Economic Co-operation and Development even if it announced a decline of 7.5 which fits in a normal range, has a pessimist scenario for 2021 with a weak recovery.

The global natural gas demand saw a major fall in 2020,4\% from last year, according to IEA projections. In an optimistic scenario demand is expected to recover in mature markets to pre-pandemic levels in 2021 and even to see additional growth. Still, the global economy will be affected by the pandemic for some time. As stated by IEA this will lead to "an average natural gas demand growth of $1.5 \%$ per annum from 2019 to 2025, according to the IEA" [4]. As long as an increase is registered it is a positive sign, but the forecast is $17 \%$ lower than the agency's pre-pandemic annual growth assumption for the same period.

Also, in order to help us to create a clearer image on how quickly could energy and gas demand recover to previous levels and/or to anticipated growth rates the correlation between economic recovery and gas demand could be used (figure 8). Countries with a large share of gas demand in their industrial sector (in Central and Eastern Europe for instance) might expect a more significant decline and rebound in gas demand due to GDP changes than countries where demand is concentrated in the power or the building sectors as these will show much less correlation with GDP growth.

Unfortunately, the oversupply situation is improbable to be overcome promptly by any reduction in production despite the US and other countries in OPEC and others initiating steps to that end. Despite these measures, in a more pessimistic way there is no visibility for a better business environment before 2023 .

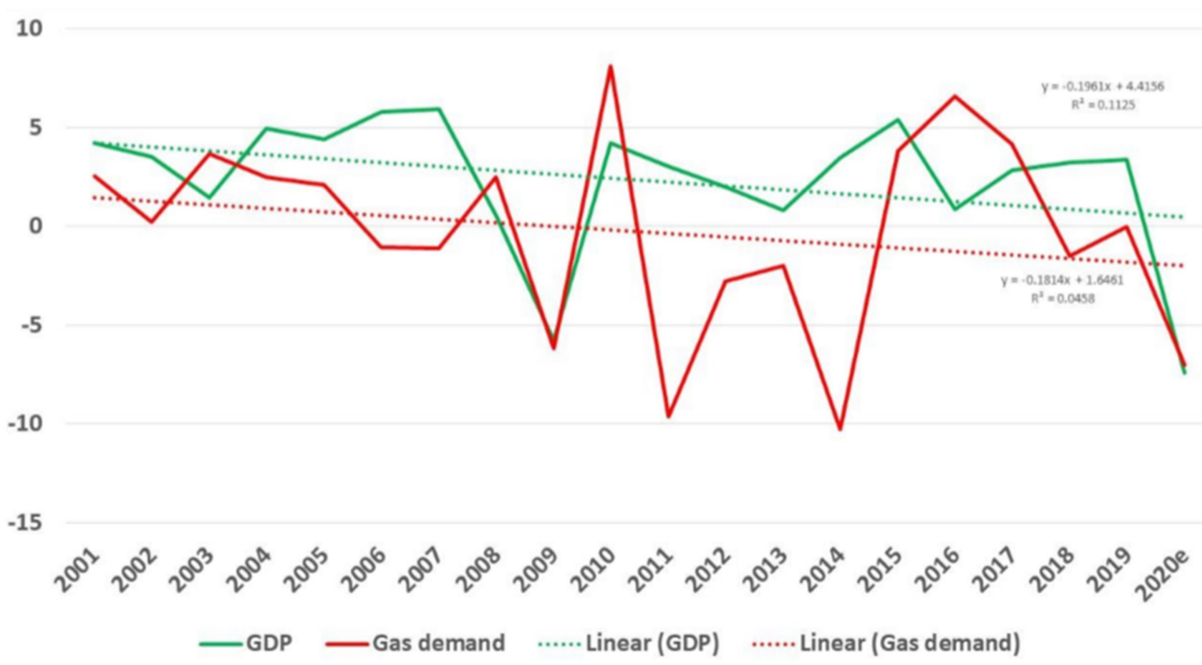

Figure 8 GDP and gas demand in Europe, 2013-2020 (per cent) [12]. 


\title{
CONCLUSION
}

The Covid-19 pandemic has inevitably resulted in an energy demand destruction and the numbers speak for themselves. The drop in the global energy demand was more than $5 \%$ in 2020 in year-on year comparison. World oil production in 2020 was $6 \%$ lower than in 2019, whereas global LNG demand fell by as much 8 percent in 2020. Natural gas use in power generation fell an estimated 2\% y/y worldwide in 2020.

The effects of COVID-19 cut European natural gas production by $23 \% \mathrm{y} / \mathrm{y}$ and European natural gas prices by $30 \% \mathrm{y} / \mathrm{y}$. Also, pipeline imports to Europe decreased by $13 \%$ due to lower inflows from Russia and North Africa.

In spite of an expected gradual recovery in 2021, the Covid-19 crisis will have longlasting impacts on natural gas markets leading to a number of behavioural changes, such as less traveling, switch from using public transport to other modes of travel, or work from home more often. Many of those doubtless will dissipate over time as the virus is brought under control and public confidence is restored, but some of them, like teleworking, may persist.

The disruptions associated with Covid-19 may encourage deglobalization as countries chase to increase their resilience by becoming less dependent on imported goods and services and companies reshore certain activities and move supply chains closer to home. As a result of this trend the concerns about energy security may increase, especially in high dependent on energy import countries.

Nevertheless, from any unpleasant event we can keep the positive aspects and learn to adapt to the changes that are coming in the industry sector. Even in the future hydrocarbons will still be an essential energy source, also as technology drivers with a widespread economic and social impact. "After all, we live in the age of hydrocarbons and much of our hopes for the future are built on the hydrocarbon molecule" [6].

\author{
ABBREVIATIONS \\ IEA $=$ International Energy Agency \\ $\mathrm{IMF}=$ International Monetary Fund \\ OECD $=$ Organisation for Economic Co-operation and Development \\ $\mathrm{OPEC}=$ Organization of the Petroleum Exporting Countries \\ US $=$ United States \\ $\mathrm{ANRE}=$ National Regulatory Authority for Energy \\ GDP $=$ Gross Domestic Product \\ $\mathrm{Y} / \mathrm{Y}=$ Year on Year \\ LNG $=$ Liquefied Natural Gas \\ Q1 = First quarter (1 January - 31 March) \\ $\mathrm{Q} 2=$ Second quarter (1 April - 30 June) \\ Q3 = Third quarter (1 July - 30 September $)$
}


Q4 = Fourth quarter (1 October -31 December $)$

$\mathrm{bcm}=$ billion cubic meters

\section{REFERENCES}

[1] Mihai-Sabin Muscalu, Marina Bădileanu, Marius-Florian Bulearcă, Andrei-Silviu Dospinescu, Luminița-Izabell Georgescu, Cornelia Neagu, Corneliu Russu, Cristian Sima, Impact Of The Covid-19 Pandemic On Some Industrial Economic Activities, National Institute Of Economic Research - Costin C. Kirițescu”, Romania, 2020, pp 3-6.

[2] Anouk Honoré, Natural gas demand in Europe: The impacts of COVID-19 and other influences in 2020, Oxford Energy Comment, United Kingdom, pp 2-8, 2020.

[3] https://energyindustryreview.com/analysis/eu-gas-consumption-and-production-inq1-2020/.

[4] BloombergNEF, Global Gas Report 2020, International Gas Union, SNAM (Transmission System Operator - Italy), pp 15-31, 2020.

[5] British Petroleum, Energy Outlook, United Kingdom, pp 29, 2020.

[6] Jan Erik, Complete Adapt and Plan for a Comeback - Oil \& Gas and the need to realign business as demand dampens, supply increases, Tata Consultancy Services, 2020 .

[7] https:/www.newschannel6now.com/2020/12/10/covid-vaccine-means-good-newsoil-gas-industry.

[8] Anouk Honoré, Natural gas demand in Europe: The impacts of COVID-19 and other influences in 2020, Oxford Energy Comment, United Kingdom, pp 3, 2020.

[9] European Commission, Quarterly Report on European Gas Markets, Volume 13, pp 6, 2021.

[10] Eurostat, local producer reports.

[11] European Energy Exchange.

[12] Anouk Honoré, Natural gas demand in Europe: The impacts of COVID-19 and other influences in 2020, Oxford Energy Comment, United Kingdom, pp 9, 2020. 